\title{
(Dis)funções da Publicidade e da Propaganda nos campos social, político e ambiental ${ }^{1}$
}

\author{
Maria Berenice da Costa MACHADO ${ }^{2}$
}

\begin{abstract}
Resumo:
Em tempos de diversidade e mais aceitação de perfis, etnias, gêneros e religiões, este estudo considera a natureza, as funções e a responsabilidade social da Publicidade e da Propaganda para tensionar os conteúdosde anúncios, slogans, jingles, capas e matérias de jornais, revistas e telejornais, filmes e minisséries com o curso da história. Identifica nas peças inconsequências e até irresponsabilidades, o que caracterizaria disfunções da Publicidade e da Propaganda, pois contrárias aos princípios da igualdade e fraternidade que devem reger a vida em sociedade. A atual vigilância digital de segmentos segregados e anteriormente impossibilitados de questionar os deslizes das campanhas pode indicar uma visível melhora comportamental. Além das suas clássicas funções, à comunicação persuasiva cabe também prever possíveis reverberações e considerar as suas responsabilidades sociais, políticas e ambientais.

Palavras-chave:

Publicidade. Propaganda.Funções.Responsabilidades.

\section{(Dis)functions of Advertising and Propaganda in social, political and environmental fields}

\begin{abstract}
:
In times of diversity and wider acceptance of profiles, races, genders and religions, this study takes into account the goal, functions and responsibilities of Advertising and Propaganda in order to confront the contents of advertisements, slogans, jingles, newspapers articles and front covers, magazines and broadcast news, films and miniseries with the course of history. Itidentifies in the ads inconsistencies and irresponsibilities even, thus characterizing disfunctions of Advertising and Propaganda, since they go against principles of equality and brotherhood underlying life in society. The present digital screening of segregated segments which not long ago were not allowed to question campaign slips can mean a visible change of behavior. Beyond its classical functions, persuasive communication should also anticipate possible reverberations and take into account its social, political and enviromental responsibilities.
\end{abstract}

Keywords:

Advertising. Propaganda.Functions.Responsabilities.

\section{(Dis)funciones de laPublicidad y Propaganda enel campo social, político y ambiental}

Resumen:

En tiempos de diversidad y másamplia aceptación de perfiles, razas, génerosy religiónes, este estudio considera el carácter, las funciónesy la responsabilidad social de la Publicidad y Propaganda para confrontar los contenidosde anuncios, slogans, jingles, tapas y artigos de periódicos, revistas y telediarios, películas y miniseries con el curso de la historia. Distingue en anuncios inconsecuencias y hasta irresponsabilidades, lo que podría caracterizar disfunciónes da la Publicidad y Propaganda, pues contrarias a los principios de igualdad y fraternidad que deben regular la vida en la sociedad. La supervisión digital actual de segmentos segregados y anteriormente imposibilitados de cuestionar los deslices de las campañas puede indicar una mejora visible de los comportamientos. Adémas de sus

\footnotetext{
${ }^{1}$ Versãorevisada e ampliada do texto apresentadona Mesa 04 - "Navegando pela história da propaganda no Brasil" - do XI Encontro nacional de História da Mídia (Alcar 2017), realizado entre os dias 08 e 10 de junho de 2017, em São Paulo, com o tema central "Manipulaçõesmidiáticas em perspectiva histórica". ${ }^{2}$ Doutora em Comunicação, Professora Adjunta do Curso de Publicidade e Propaganda da Faculdade de Biblioteconomia e Comunicação da Universidade Federal do Rio Grande do Sul (Fabico/UFRGS). Email: mberenice.machado@ufrgs.br
} 
funciónes clásicas, la comunicación persuasiva debe también prever possibles reverberaciones y considerar sus responsabilidades sociales, políticas y ambientales.

Palabras clave:

Publicidad. Propaganda. Funciónes. Responsabilidades.

\section{Introdução}

Um anúncio em preto e branco, de página inteira, veiculado em março de 1999, na Revista Consumidor S.A. (nº 4, p. 28 apud PUBLICIDADE..., 2002, p. 30), exibe uma fotomontagem: Hitler com aparência jovem e as mãos simulando uma pomba em frente ao peito ${ }^{3}$. Sobre as mãos a mensagem: "Cuidado com a propaganda enganosa", a assinatura "IDEC - Instituto de Defesa do Consumidor" e a recomendação "Consulte nosso site: www.idec.org.br".

No seu tempo-lugar, Hitler, mestre na arte da propaganda política, até poderia ter se autointitulado da paz, do bem e do progresso com o objetivo de arregimentar seguidores e com eles levar adiante o seu plano diabólico. Entretanto, a realidade social foi se impondo até a derrota do projeto nazista.

Peças como a do IDEC tangibilizam e desvelam as possibilidades de manipulação das mídias. A óbvia e proposital contradição entre o líder-exterminador e a pose pacifista, obtida a partir de originais trabalhados digitalmente, serve como metáfora para o conceito da campanha, compatível com a natureza da comunicação persuasiva, que produz sentidos a partir de representações imagéticas e textuais para atender aos objetivos de quem a anuncia.

Neste estudo articulamos reflexão que envolve um conjunto de peças e ações propagandísticas e publicitárias ${ }^{4}$ bem sucedidas nos seus objetivos ideológicos e/ou comerciais nos períodos em que foram concebidas e veiculadas, mas que, com o passar do tempo, mostraram-se contrárias aos interesses da coletividade em questões que envolvem práticas, hábitos e costumes sociais, ambientais ou políticos. Formatos e mídias diversas são os objetos da análise, que tem caráter qualitativo e está fundamentada, principalmente, por teóricos da Publicidade e da Propaganda ${ }^{5}$ (PP).

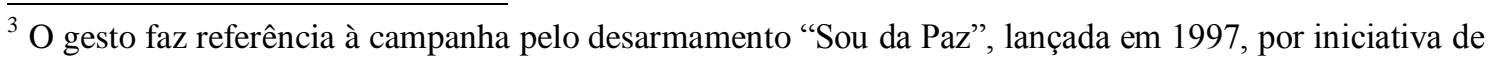
um grupo de estudantes. Essa campanha originou o Instituto Sou da Paz (INSTITUTO SOU DA PAZ, s.d.).

4 Aos tradicionais formatos da Propaganda e da Publicidade integramos ações de comunicação de natureza persuasiva, que consideramos estratégicas para influir sobre a conduta dos receptores (PINHO, 1990).

${ }^{5}$ Empregamos o termo Propaganda como o esforço persuasivo ideológico (particularmente, o de caráter político), sem fins comerciais, que pode assumir qualquer formato; e Publicidade como ligada à persuasão de caráter comercial, que visa promover bens, serviços, ideias, marcas, na forma de anúncios
} 
Consideramos as funções e a responsabilidade social da comunicação persuasiva para tensionar os conteúdos ${ }^{6}$ de anúncios, slogans, jingles, capas e matérias de jornais, revistas e telejornais, filmes e minisséries com o curso da história.

\section{"Verdades" não contestadas}

É da natureza da Publicidade e da Propagandarepresentar e "construir verdades"7, que podem assumir infinitos formatos (DOMENACH, 1955) e serem potencializadas pelo atual leque de recursos e tecnologias. Truques sonoros-visuais, angulações de câmeras, montagens ou edições de originais, uso de chromakey e Photoshop, dentre outros, contribuem para a execução e a produção da ideia-conceito planejada para a comunicação, para que chame a atenção, gere identificação e, se possível, também divirta o público. Para atingir o seu alvo, a PP usa os meios de comunicação de massa e outros que lhes são próprios, tendo como princípios a criatividade e a ousadia visando a mexer com os sentidos, as emoções ou com a razão do receptor.

Anunciantes e agências desempenham as suas funções comunicacionais e econômicas seguindo a "retórica do capital" (ROCHA, 2004) para construir a boa vontade da "opinião pública" e/ou converter parte dela em consumidores efetivos dos seus produtos, serviços e marcas. A comunicação persuasiva, além de informar, busca fazer-se crível para, assim, influenciar a conduta ideológica e/ou comercial dos receptores-consumidores. Trabalho prévio é captar e interpretar os desejos coletivos latentes que são devolvidos ao público na forma de mensagens cujas funções são aproximar emissor-produtor-anunciante dos seus potenciais alvos para mudar ou reforçar as suas opiniões em relação à determinada ideologia, projeto, partido ou candidato, ou ainda para estimular a adesão e o consumo de produtos, serviços e marcas.

Se o conteúdo da PP deve chamar a atenção e gerar identificação com seu alvo, o sucesso de peças e campanhas seria indicador de sintonia e pacto com a sociedade, condição observada por McLuhan em livro escrito em 1964: "Os historiadores e

pagos,veiculados nos meios de comunicação de massa ou em ações direta, por um patrocinador identificado (DIONÍSIO et al, 1999, p. 44-6).

\footnotetext{
${ }^{6}$ Nas peças publicitárias privilegiamos o elemento slogan por sua capacidade de sintetizar o conceito criativo da campanha (REBOUL, 1986).
}

${ }^{7}$ Slogan da premiada série MadMen. Los Angeles: AMC, 2007 a 2015. Programa de TV. 
arqueólogos um dia descobrirão que os anúncios de nosso tempo constituem os mais ricos e fiéis reflexos diários que uma sociedade pode conceber para retratar todos os seus setores de atividade" (MCLUHAN, 1969, p. 262). A PP, também produto da realidade que a cerca, acostumou-se a refletir, reproduzir e reforçar, sem questionar, os valores e a moralidade social, as leis e a ética, a cultura, a tecnologia, as relações econômicas, políticas. Tampouco foi contestada publicamente. Excluindo a parte que adere e concorda com os conteúdos propagandísticos e publicitários, creditamos tal "silêncio" à impossibilidade dos sujeitos inconformados reverberarem e se fazerem ouvir, situação que se alterou com as tecnologias e redes digitais a partir dos anos 2000.

\section{(Dis)funções da Publicidade e Propaganda}

A revisão de peças publicitárias e ações de propaganda objetiva cotejar os argumentos criativos com as funções da comunicação persuasiva. Partimos de “annuncios" inseridos nos primeiros jornais brasileiros, fundados no início do século 19 , cujos objetivos foram propagar e tornar pública a venda de "huma morada de cazas de sobrado", de negros, animais, imóveis, remédios, entre outras mercadorias, ou ainda gratificar quem pegasse e entregasse "escravo fugido" (MARTINS, 1997, p. 24-27). A luta abolicionista, iniciada ainda nesse século, poderia ser entendida como contestação à venda de pessoas e sua equiparação a animais. Entretanto, os atuais movimentos pela igualdade de cor e o combate ao racismo são indicadores de que essa luta ainda persiste.

\section{- Queimando vidas}

Durante a primeira metade do século 20, com a vinda de indústrias multinacionais para o País, a comunicação, além de apresentar os produtos, deveria ensinar como poderiam ser usados e quais seriam os seus benefícios para a saúde e o bem-estar. Maciços investimentos em publicidade tiveram funções pedagógicas e até civilizadoras, visando a promover produtos de limpeza e higiene, eletrodomésticos, cigarros, bebidas alcoólicas, carros velozes, alimentos ultraprocessados, cadeias de fastfood. Foram frequentes nesse período, em jornais e revistas coloridas, anúncios exibindo homens fumando com argumentos que variavam: "É costume que as moças e as senhoras não digam mais aos seus noivos e maridos para não fumar (...) esta marca evita o mau hálito, possui perfume agradável, capaz de deliciar as mulheres, é higiênica e chique" (FON FON, 1914, p. 73. A indústria tabagista também empreendeu esforços 
para atingir o imaginário feminino: atores famosos de Hollywood, médicos, dentistas, bebês robustos e atletas recomendavam cigarro para acalmar os nervos, dar energia e perder peso (MACHADO, 2009).

Após o "Maio de 68 na França", período em que o mundo foi sendo tomado por valores até então subversivos, os jovens cheios de utopias e fantasias passaram a centro das atenções e rapidamente foram incorporados ao sistema pelos meios de comunicação. As marcas de cigarro dirigidas a esse segmento pregavam a liberdade em versões e imagens de esportes radicais (MACHADO, 2009). Paralelamente, foi se desenhando um quadro epidêmico de doenças ligadas ao hábito de fumar. Instituições de saúde e governos promoveram e patrocinaram campanhas, muitas vezes polêmicas, para alertar sobre os malefícios do fumo.

\section{- Aquecendo a cama}

Ainda na segunda metade do século 20, registramos a Era de Ouro da Publicidade e Propaganda, abundante em inserções nas mídias e campanhas memoráveis $^{8}$. Muitas delas parecem comungar inconsequências em relação aos interesses da sociedade. É o caso do filme Cobertores Parahyba, um dos primeiros em animação produzidos no Brasil, veiculado sempre às 21h na televisão, entre $1960 \mathrm{e}$ 1975, e considerado dos mais lembrados (CAMPANHAS..., 2007, p. 18). Naqueles primórdios da televisão, o jingle indicava a "hora de dormir": na tela, crianças de pijama e gorro recebiam o beijo da mãe e dirigiam-se à cama carregando uma vela na mão. Não se tem notícia de quantas queimaduras, incêndios ou discussões entre pais e filhos o conjunto criança, vela e cama possa ter provocado. Podemos inferir alguns "desastres" que a simpática campanha possa ter provocado. Além dessa razão, a cena faz lembrar que em muitas regiões brasileiras a luz elétrica ainda não tinha chegado para iluminar, refrigerar e fazer funcionar a televisão.

\footnotetext{
${ }^{8}$ A editora Meio \& Mensagem (M\&M) organizou, em 2017, o livro Campanhas inesquecíveis: propaganda que fez história no Brasil, reunindo 84 campanhas memoráveis, veiculadas entre os anos de 1960 e 1995, período em que as mídias de massa passaram por forte desenvolvimento. O critério da seleção foi terem elevado os produtos anunciados à condição de ícones do consumo de sua época, de terem estabelecido relações emocionais com o público e permaneceram na sua memória afetiva. O texto observa seus ingredientes: criatividade, ousadia, ineditismo e pesados investimentos em mídia, reveladores do esforço técnico e persuasivo para dar visibilidade à mensagem e provocar no público-alvo um sentimento de identificação e adesão. Observamos, entre as 84, quatro marcas de cigarros e sete de bebidas alcoólicas, produtos com as regras de publicidade e veiculação alteradas nos últimos anos.
} 


\section{- Perfume sem limite}

Outra campanha memorável foi para o lançamento de produto no segmento de sabonetes desodorantes, deflagrada em 1967 pela Unilever e a agência Lintas. Para sintetizar o conceito de inclusão, o slogan "Sempre cabe mais um quando se usa Rexona" foi estampado em anúncios de revistas voltadas ao público feminino. Posteriormente, o sabonete foi parar na televisão com comerciais que exibiam uma jovem deliciando-se no banho com Rexona. Na cena seguinte, ela saía exalando o seu aroma, deparava-se com ambientes lotados - houve versões em bonde, carroça, elevador, carro, trem e lancha - e aceitava o convite dos ocupantes, geralmente rapazes, entrando no local bastante cheio. Em alguns dos roteiros a garota foi trocada pela figura do azarado, um jovem franzino e de óculos (CAMPANHAS..., 2007, p. 26-27).

O slogan "Sempre cabe mais um" permaneceu identificando a marca até a década de 1990, portanto, não é de estranhar que tenha sido incorporado ao vocabulário popular brasileiro e empregado em situações diversas em que há excesso de pessoas em relação ao espaço disponível. Independente das questões sexistas e do constrangimento provocado ao "excluído", tais roteiros e slogan banalizaram a segurança dos ocupantes e podem ter contribuído para a cultura da superlotação, que teve como consequência casos desastrosos, como os do BateauMouchee da boate Kiss ${ }^{9}$.

\section{- Sujo não contesta}

A campanha protagonizada pelo personagem Sujismundo, com o slogan "Povo desenvolvido é povo limpo", foi promovida e veiculada pelo governo federal (General Médici, 1969-1973) com o objetivo de conscientizar e melhorar os hábitos de higiene e limpeza dos brasileiros. Com técnica de desenho animado, os filmetes foram exibidos na televisão, entre 1971 e 1972, para mostrar os erros de conduta e os maus hábitos do

\footnotetext{
${ }^{9}$ BateauMouche foi uma embarcação de turismo que naufragou na Baía de Guanabara, no Rio de Janeiro, no dia 31 de dezembro de 1988, durante a tradicional queima de fogos em Copacabana, matando 55 pessoas. As investigações apontaram que a embarcação estava superlotada, não havia passado por vistoria e nem tinha equipamentos de proteção para todos os 142 passageiros que estavam a bordo. O incêndio na boate Kiss, na madrugada do dia 27 de janeiro de 2013, na cidade de Santa Maria, no Rio Grande do Sul, matou 242 pessoase deixou feridas outras 680. A causa seria um sinalizador disparado no palco por um integrante da banda que lá se apresentava, imprudência potencializada pelas más condições de segurança e a superlotação do local.
} 
personagem, por exemplo, jogar lixo no chão. Sugismundo virou sinônimo de porcalhão. Mesmo assim, naquela mesma década ainda apareceu em tiras de histórias em quadrinhos e gibis com pretensões educativas. A pedagogia pelo viés negativo não suscitou a virada, ou seja, não motivou a população. A popularidade do "anti-heroi", ao invés de combater, pode até ter incentivado a sujeira, além de prejudicar ainda mais a imagem e a autoestima do povo brasileiro. Durante a ditadura militar, a campanha não foi contestada (CAMPANHAS..., 2007, p.42-43).

\section{- Jatos dispersos}

Um exemplo que ilustra apologia ao desperdício de recursos naturais é o comercial de lançamento das Duchas Corona, chuveiro feito de plástico voltado às camadas populares, veiculado em 1972. O jingle "um banho de alegria num mundo de água quente" fez tanto sucesso que "acabou se transformando em trilha sonora de todos os comerciais da empresa nos 12 anos seguintes" (CAMPANHAS..., 2007, p. 56-7). Mais adiante, em 2006, a canção tocou também em displays interativos afixados em algumas revendas do produto. A cena final na televisão exibia a ducha, uma grande catarata e a frase-assinatura: "Troque seu banho de pingos por um banho de jato" (CAMPANHAS..., 2007, p. 56-7). Não podemos medir o quanto a imagem-estímulo do

banho-cachoeira, veiculada por 12 anos, pode ter contribuído para a atual escassez de água potável. Atualmente, os chuveiros são projetados para consumir menos energia elétrica, sua publicidade estimula e ensina sobre o prazer de economizar água e luz.

\section{- Lei do contra}

Conjugação publicitária delicada foi protagonizada pelo jogador Gérson, conhecido como "cérebro" da Seleção Brasileira de Futebol tricampeã na Copa do Mundo de 1970. No comercial para a marca de cigarros Vila Rica, veiculado dois anos após o título, enquanto o atleta e seu entrevistador acendiam seus "bastões de nicotina", este último faz um pedido precedido pelo aval "Gérson, você que sempre fumou, explique a sua preferência". Resposta: "É gostoso, suave e não irrita a garganta (...) por que pagar mais caro se o Vila me dá tudo aquilo que eu quero de um bom cigarro? Gosto de levar vantagem em tudo, certo? Leve vantagem você também (...)" (CAMPANHAS..., 2007, p. 66-7).

As últimas frases ficaram conhecidas na cultura popular e midiática como a "Lei 
de Gérson": um mantra que poderia justificar atitudes pouco éticas, resumo de malandragem, desonestidade e jeitinho. Tal mote para a criação, segundo a agência, teria vindo das regras do futebol: se um jogador sofrer falta e estiver de posse da bola, aplica-se a "lei da vantagem", ou seja, não é preciso parar a partida. O texto no livro da Meio \& Mensagem observa, já no início do capítulo, que "campanha semelhante jamais seria veiculada nos dias de hoje" (CAMPANHAS..., 2007, p. 66-7) e aponta razões de ordem legal (restrição à publicidade de cigarros desde 2001) e de associar um ídolo esportivo com o hábito de fumar, depois das campanhas sobre os seus malefícios promovidas pelas autoridades de saúde e pela mídia. Tanto o jogador quanto a equipe de criação ressentem-se da "avassaladora interpretação antropológica" que associou a campanha a oportunismo (CAMPANHAS..., 2007, p. 66-7). Independente dessas questões, que têm a ver com a cultura do período em que veiculou, o conceito reforça o egoísmo e nega um dos princípios básicos da vida em sociedade: para um levar vantagem, outro sairá em desvantagem (oportuno destacar que o texto ainda frisava: "levar vantagem em tudo").

\section{- Viradas globais}

O processo de redemocratização do Brasil, após o Golpe de 1964, cumpriu rito fundamental em 1989 com a eleição presidencial pelo voto direto da população. 22 homens e uma mulher candidataram-se ao cargo ${ }^{10}$, em campanha disputada em dois turnos que acelerou os campos social, político e midiático (RUBIM, 2000). Os debates eleitorais na televisão brasileira tiveram destaque, pois extrapolaram a sua realização, dada a questão que surge após os seus términos: identificar quem se saiu melhor e quem seria o derrotado. Weber e Abreu, (2010, p. 170) denominam "repercussão encadeada" o processo posterior ao debate político-eleitoral na televisão no qual respostas diversas são dadas pela mídia, que apresenta a sua versão avalizada pelos resultados de pesquisa junto aos espectadores-eleitores, encomendada previamente. O material serve ainda para produzir imagens, análises e comentários em jornais, telejornais, blogs, sites especializados em jornalismo político, revistas, etc. Os debatedores também apresentam

\footnotetext{
${ }^{10} \mathrm{Em}$ ordemdecrescente, conforme a votação no primeiro turno: Fernando Collor de Mello (PRN), LuizInácio Lula da Silva (PT), Leonel Brizola (PDT), MárioCovas (PSDB), Paulo Maluf (PDS), Guilherme Afif Domingos (PL), Ulysses Guimarães (PMDB), Roberto Freire (PCB), Aureliano Chaves (PFL), Ronaldo Caiado (PSD), Affonso de Camargo Neto (PTB), Enéas Carneiro (PRONA), José Alcides Marronzinho (PSP), Paulo Gontijo (PP), Zamir José Teixeira (PCN),LíviaMaria Pio (PN), Eudes de Oliveira Mattar (PLP), Fernando Gabeira (PV), Celso Teixeira Brant (PMN), Antônio dos Santos Pedreira (PPB), Manoel de Oliveira Horta (PDC do B), Armando Correa da Silva (PMB) e Silvio Santos (PMB). Este último teve a candidatura indeferida.
} 
as suas narrativas em edições que veiculam nos seus programas eleitorais durante o Horário Gratuito de Propaganda Eleitoral (HGPE).

No primeiro turno da eleição de 1989 foram realizados seis debates, com a participação de dez candidatos. O melhor colocado nas pesquisas de intenção de voto, Fernando Collor de Mello, do Partido da Reconstrução Nacional (PRN-AL), não participou de nenhum. No segundo turno, Collor enfrentou o adversário Luiz Inácio Lula da Silva, do Partido dos Trabalhadores (PT-SP) em dois debates televisivos, promovidos por pool das principais emissoras brasileiras, Bandeirantes, Globo, Manchete e SBT. O primeiro debate foi realizado no dia 3 de dezembro, nos estúdios da TV Manchete (RJ), e o segundo, no dia 14 daquele mesmo mês, na TV Bandeirantes (SP) (MACHADO, 1991).

Desde o primeiro confronto televisivo, as imagens de Collor e Lula não deixavam dúvidas em relação às origens político-partidárias e às classes sociais, culturais e econômicas que representavam. O debate inicial teve como características o equilíbrio, o respeito às regras e a polidez entre os candidatos. Lula, apesar dos erros gramaticais e do vocabulário básico, demonstrou raciocínio rápido, com uso de frases curtas e coloquiais, que o auxiliaram a livrar-se das armadilhas de Collor. As pesquisas de opinião apontaram Lula como vencedor, desempenho que impressionou Collor e motivou sua assessoria a divulgar que "nos próximos atos e debates da campanha pretendia apresentar ao eleitorado o radicalismo de esquerda do opositor" (MACHADO, 1991, p. 65).

As condições que antecediam o último debate televisivo do segundo turno indicavam Collor em primeiro lugar nas pesquisas, mas apresentando gradativa queda. Lula estava em ascensão, fato que pode ter colaborado para o clima hostil conjugado às acusações contra Lula veiculadas naquela semana no programa do PRN, no HGPE. Havia muita expectativa por parte dos eleitores quanto ao desempenho dos candidatos, a partir dos resultados do primeiro debate e da grande repercussão que alcançou. A audiência foi significativa naquele que seria o último ato oficial da campanha, pois estariam em confronto na tela da televisão dois estilos, ideologias e projetos. Entretanto, o processo contou com a "participação" da mais poderosa emissora de televisão brasileira. No dia seguinte e em horário nobre, a Rede Globo repercutiu o debate, apresentando a sua edição nos jornais Hoje e Jornal Nacional. 
Importa observar que Roberto Marinho foi padrinho de Fernando Collor no seu primeiro casamento, em 1975, e que as famílias Marinho e Arnon de Mello eram parceiras em negócios como o da TV Gazeta de Alagoas, afiliada da TV Globo. O episódio da edição do debate de 1989, objeto de estudos acadêmicos desde então, ratifica a participação midiática da Globo para favorecer política e eleitoralmente o seu apadrinhado (LATTMAN-WELTMAN, 1994).

Em 2010, ainda durante o segundo mandato de Lula (PT) e às vésperas de mais uma eleição presidencial, o assunto foi pautado e publicado no site Memória Globo. $\mathrm{O}$ texto admite "um inequívoco dano à imagem da TV Globo" e justifica que o Jornal Nacional seguiu "o mesmo critério de edição de uma partida de futebol, na qual são selecionados os melhores momentos de cada time" (MEMÓRIA GLOBO, s.d.). Segundo os profissionais da Globo, "o objetivo era que ficasse claro que Collor tinha sido o vencedor do debate, pois Lula realmente havia se saído mal" (MEMÓRIA GLOBO, s.d.). Desde então, esclarece o documento, “a emissora adota como norma não editar debates políticos; eles devem ser vistos na íntegra e ao vivo". E conclui: "Um debate não pode ser tratado como uma partida de futebol, pois, no confronto de ideias, não há elementos objetivos comparáveis àqueles que, num jogo, permitem apontar um vencedor" (MEMÓRIA GLOBO, s.d.?).

A intervenção social e política da TV Globo não parou na edição do segundo debate da eleição de 1989. Fernando Collor assumiu a Presidência da República em março de 1990, com inflação que beirava os $80 \%$. Com o apoio da sociedade, da mídia e do Congresso Nacional, ele tentou implementar um ousado plano de orientação neoliberal, que previa reformas administrativas e privatizações. Não obteve sucesso e o País voltou à recessão econômica. Paralemente, Collor enfrentou denúncias de corrupção euma Comissão Parlamentar de Inquérito (CPI).

A crise política acentuou-se a partir de maio de 1992, com a decisiva participação da mídia, com acusações em entrevistas e reportagens e destaque nas capas, como as das revistas Veja e Isto É e o noticiário da Rede Globo. Este grupo de comunicaçãoproduziu e exibiu em rede nacional de televisão, entre os dias 14 de julho e 14 de agosto daquele mesmo ano, a minissérie Anos Rebeldes, inspirada na trajetória de jovens estudantes durante o período do Regime Militar (1964-85). Como que acordados pela ficção serial, os jovens brasileiros saíram às ruas nas principais cidades do País com as caras pintadas para gritar "Fora Collor!". A votação de 
seuimpeachment aconteceu em 29 de setembro de 1992.

A Globo apoiou a ascensão de Collor ao cargo máximo do Executivo Nacional, ao transmitir e depois editar o último debate da campanha de 1989. Quando Collor não lhe interessava mais, orquestrou campanha até a sua deposição. Amea culpa em relação ao apoio dado a Collorviria anos mais tarde no site Memória, talvez para higienizar a sua abalada imagem.

\section{Transformações no sistema publicitário}

Estudos acadêmicos vêm registrando profundas alterações no campo da comunicação publicitária e propagandística. Seus conceitos expandem-se até transbordar (PEREZ, 2016), hibridizam-se (COVALESKI, 2010) ou promocionalizamse (CASTRO, 2013); há integração entre as tradicionais campanhas com ações de outras áreas da Comunicação, como o Jornalismo, a Assessoria de Imprensa, o Design e as Relações Públicas. As tecnologias digitais, que a partir da década de 1990 redesenharam os modelos de negócios e reduziram os custos na cadeia produtiva, mexeram com os regimes de visibilidade ao somarem o ciberespaço às tradicionais mídias massivas: sites, blogs, aplicativos, games e redes sociais, com custos ínfimos se comparados aos dos grandes veículos, democratizaram as possibilidades de manifestação e multiplicaram as formas de contato e circulação de opiniões, produtos, serviços e marcas, que agora se lançam ou ativam para atingir grandes grupos ou pequenos nichos.

Além da ampliação da oferta de comunicação e de meios, outra característica da atualidade que vem balizando a PP é a economia baseada em intangíveis, experiências, lazer, espetáculos, jogos e turismo que passaram também a disputar a atenção do receptor, que busca, nesses conhecimentos, conteúdos relevantes e entretenimento. $\mathrm{O}$ humor na publicidade, outrora um recurso fácil para cumprir tais tarefas, tem agora que ser mais inteligente, pertinente, social e politicamente correto. Além das suas clássicas funções, a PP precisa considerar a responsabilidade social, moral, política e ecológica em relação ao consumo.

Tomamos como exemplo o jingle do comercial de Detefon, veiculado em 1945 (DETEFON, 2017): o argumento para eu "não ir na sua casa", pois lá havia baratas e outros insetos, desatentava para as subjetividades, relações e inserções dos sujeitos receptores-consumidores. Atualmente, para propagar o extermínio de baratas e outros insetos (haveria alguma casa que nunca recebeu esses visitantes indesejados?), a 
abordagem tem que considerar os animais, o ambiente e as pessoas. Uma prevenção a constrangimentos, como o ocorrido em uma sala de autoatendimento de um banco: mulher que aguardava na fila viu uma barata e "avisou" ao sujeito que estava na sua frente. Imediatamente, ele respondeu: "eu não posso matá-la, sou biólogo".

\section{Era de respostas múltiplas e imediatas da sociedade}

Com a democratização do acesso às mídias e o potencial de reverberação dos ambientes digitais, tem sido frequentes as polêmicas envolvendo campanhas e anúncios $^{11}$, como estes dois casos registrados em 2016 envolvendo grandes grupos de publicidade. Em janeiro, os filmes "digitau" para televisão visavam promover os canais de atendimento digitais do banco Itaú. Mesmo a agência Africa tendo reforçado que a forma ortográfica correta de digital é com "l”, que digital com "u" seria "apenas um jeito bem-humorado e publicitário de apresentar o novo apelido do Itaú para sua atuação no mundo digital", a reclamação chegou ao Conar. A criação amparou-se na "licença publicitária", que outrora permitiu trocadilhos e corruptelas do português. Entretanto, o episódio do banco oferece oportunidade para questionar se em um país com tantos analfabetos compensa o risco de induzir a erros de ortografia para propagar as operações digitais do Itaú.

O segundo caso foi analisado por Fábio Bernardi, sócio-diretor de criação da Morya em Porto Alegre e ex-presidente da Associação Riograndense de Propaganda. No artigo Publicidade engajada ele compara a mesma ideia-conceito de duas campanhas premiadas no Festival Internacional de Criatividade, em Cannes: a do Ministério do Turismo de Aruba (BERNARDI, 2016), em 2006, e a da Aspirina Bayer (CAMPANHA..., 2016), em 2016. Texto da primeira: "Eu disse a ela que a câmera estava desligada. (Ninguém é bom o suficiente para ir para o céu. Vá para Aruba)", ganhou leões sem suscitar qualquer polêmica.

A outra peça, "Calma amor, não estou filmando isso.mov"12 (CAMPANHA DA ASPIRINA..., 2016) desenvolvida pela AlmapBBDO com a mesma ideia, conquistou

\footnotetext{
${ }^{11}$ Em agosto de 2017, o Conselho Nacional de Autorregulamentação Publicitária (Conar) veiculou a campanha "Opções", criada pela AlmapBBDO. Uma das versões apresenta a tela dividida ao meio e a imagem de mulheres semelhantes, uma magra e a outra gorda. O áudio questiona: "Já pensou se todo comercial tivesse que ter opções para agradar todo mundo?". E explica: "Por isso que existe o Conar. Para separar o que é gosto pessoal do que é ofensivo e ilegal". Imediatamente a campanha foi contestada, sob os argumentos de que gosto e diferenças de pontos de vista são diferentes de preconceito e discriminação. (CONSELHO..., 2017).

${ }^{12}$.mov é um dos formatos de vídeos populares na internet.
} 
dois "leões de bronze" (terceira colocação nas categorias outdoor e print) com uma ação feita para a marca de medicamento Aspirina, da Bayer, que sugere filmagem e divulgação não consensual de vídeos íntimos na web. Provocou muita "dor de cabeça" à agência de publicidade: críticas no Facebook e em outras redes sociais reclamaram da peça e, inclusive, sugeriram denúncia ao Conar como sexista, machista, estimuladora da pornografia e da violência.

Internautas fizeram comentários na época, publicados no Portal $\mathrm{G} 1{ }^{13}$ : "É sério mesmo que vocês acharam que dizer em uma campanha publicitária, que compartilhar fotos e vídeos íntimos daria dor de cabeça e para resolver esse incômodo seria só tomar uma Aspirina?”; "Em que bolha vivem os publicitários que criaram essa campanha? Quantas mulheres trabalham na Almap? Quantas estão em posição de liderança?’”.

Os problemas da agência não se restringiram ao público. O Laboratório Bayer, fabricante da Aspirina, afirmou em nota divulgada no Portal G1 (APÓS..., 2016): "A exibição do conteúdo no festival ficou por conta da AlmapBBDO [...] a veiculação foi de responsabilidade da agência a fim de atender os requisitos para submissão em Cannes". E solicitou a descontinuidade da campanha.

No mesmo canal G1, a agência de publicidade posicionou-se sobre a polêmica, lamentando o ocorrido, garantindo que não teve a intenção de ofender as mulheres e informando que pediu à organização do festival de Cannes a retirada de todas as peças criadas para a Bayer. "Repudiamos a prática de filmagem não consensual e qualquer espécie de violência ou invasão de privacidade. Ficaremos atentos para evitar o problema no futuro" (APÓS..., 2016). Perda dos prêmios foi o dano menor para a AlmapBBDO.

Se o caso deu dor de cabeça, dá também o que pensar: nesse pequeno intervalo de tempo, dez anos, não ser mais aceita abordagem como essa é um sinal claro de uma visível melhora no comportamento social e a vigilância diante dos deslizes da publicidade.

\section{Considerações finais}

Inegável que a sociedade está mudando e obriga que muita coisa mude com ela, inclusive a Publicidade e a Propaganda. Historicamente, se essas serviram, sem questionar, ao tecido industrial - cujo objetivo principal sempre foi produzir riquezas -

\footnotetext{
${ }^{13}$ Os comentáriosestavamdisponíveis no Portal G1 na data do acesso, em 2016.
} 
e a causas ligadas aos campos social e político, agora não é mais possível relevar que, na maioria das vezes, as lógicas são diferentes e até antagônicas.

As contestações, abafadas pela incapacidade técnica de reverberação da sociedade, liberaram-se com o advento da Internet, que democratizou os regimes de visibilidade. Os processos de comunicação multiplicaram-se e estão mais complexos, assim como os cidadãos - receptores e consumidores - que são cada vez mais diversificados, (re)ativos, exigentes, analistas, críticos e reflexivos sobre o tempo e o lugar onde vivem. Se até à Revolução Digital estiveram privados do acesso às mídias, agora, além de mais atentos e participantes, todos têm voz e vez nas redes sociais, disputam lugares de mediação entre as esferas da produção e do consumo, inserem-se, atuam, emitem opiniões e (re)produzem informação, atraem anunciantes e corroem parte das receitas publicitárias até então sob controle dos monopólios de mídia.

Na sociedade do século 21, a da diversidade que a faz tão rica, como transitar pelo complexo, como comunicar? Considerando o poder de persuasão e a função pedagógica implícita na Publicidade e Propaganda, e que vivemos tempos de mais aceitação de etnias, gêneros, religiões, são muitas as responsabilidades da comunicação, implicando na avaliação prévia das possíveis repercussões que a mensagem publicitária poderá ter nos campos social, político e ambiental.

Neste texto revisamos um conjunto de ações, estratégias e anúncios de natureza publicitária e propagandística, traduções de objetivos e projetos de grupos hegemônicos para vender produtos, serviços e marcas, ou para (trans)formar opiniões, produzir consensos, controlar ou até manipular o tecido social. Identificamos nos seus conteúdos inconsequências e até irresponsabilidades, o que caracteriza disfunção da PP, pois contraria os princípios da vida em sociedade. Oportuno lembrar que esta carece de mais estímulos positivos para assim aprimorar e tornar mais saudável, igualitária, fraterna e justa a convivência entre as pessoas e com a natureza.

\section{Referências}

APÓS polêmica, AlmapBBDO pede retirada de peça premiada em Cannes. G1/O Globo. 24 jun. 2016. Disponível em: <http://g1.globo.com/economia/midia-emarketing/noticia/2016/06/apos-polemica-almapbbdo-pede-retirada-de-peca-premiadaem-cannes.html>. Acesso em: 10 out. 2016.

BERNARDI, Fábio. Publicidade engajada. GaúchaZH[Zero Hora], Porto Alegre, 28 jun. 2016. Disponível em:

<https://gauchazh.clicrbs.com.br/opiniao/noticia/2016/06/fabio-bernardi-publicidade- 
engajada-6223404.html>. Acesso em: 28 jun. 2016.

CAMPANHA da aspirina causa revolta nas redes sociais. Exame, 2016. Disponível em: $<$ https://exame.abril.com.br/marketing/campanha-da-aspirina-causa-revolta-nas-redessociais/>. Acesso em: 10 out. 2016.

CAMPANHA da aspirina premiada em Cannes gera protestos na web. G1/O Globo, 24 jun. 2016. Disponível em: <http://g1.globo.com/economia/midia-e-

marketing/noticia/2016/06/campanha-da-aspirina-premiada-em-cannes-gera-protestosna-web.html>. Acesso em: 10 out. 2016.

CAMPANHAS inesquecíveis:propaganda que fez história no Brasil. São Paulo: Ed. Meio \& Mensagem, 2007.

CASTRO, Maria Lília Dias de. Da publicidade ao conceito de promocionalidade: percursos e desafios. In: TRINDADE, Eneus; PEREZ, Clotilde (Org.). Por uma publicidade livre sempre. E-book. São Paulo: Inmod/ABP2/PPGCom-ECA-USP, 2013, v. 1, p. 582-598. Disponível em:

<http://www2.eca.usp.br/propesq/downloads/ebook_IV_Propesq_pp.pdf $>$. Acesso em: 10 abr. 2017

CONSELHO Nacional de Autorregulamentação Publicitária (Conar). Opções [campanha]. Ago. 2017. Disponível em:

<http://www.meioemensagem.com.br/home/comunicacao/2017/08/18/conar-avalia-seira-julgar-sua-propria-campanha.html>. Acesso em: 20 jan. 2018.

COVALESKI, Rogério Luiz. Publicidade híbrida. Curitiba: Maxi Editora, 2010.

DETEFON - na sua casa tem mosquito. Jingle. [1945, publicado on-line em 26 out. 2017]. Disponível em: <https://www.youtube.com/watch?v=G_GIRCVeZik>. Acesso em: 05 jan. 2018.

DIONÍSIO, Pedro et al. Publicitor. Lisboa, Portugal: Dom Quixote, 1999.

DOMENACH, Jean-Marie. Propaganda política. São Paulo: DIFEL, 1955.

FON FON. Cigarros Vanille [anúncio]. Rio de Janeiro, p. 73, 21 jul. 1914. Disponível em:

<http://objdigital.bn.br/acervo_digital/div_periodicos/fonfon/fonfon_1914/fonfon_1914 _029.pdf>. Acesso em: 05 jan. 2018.

INSTITUTO SOU DA PAZ. [S.d.]. Disponível em:

<http://www.soudapaz.org/institucional/historia>. Acesso em: 20 maio 2017.

LATTMAN-WELTMAN, Fernando; CARNEIRO, José Alan dias; RAMOS, Plínio de 
Abreu. A imprensa faz e desfaz um presidente. Nova Fronteira: Rio de Janeiro, 1994.

MCLUHAN, Marshall. Os meios de comunicação como extensões do homem. São Paulo: Cultrix, 1969.

MACHADO, Maria Berenice. O duelo final: Collor e Lula.Porto Alegre: UFRGS, 1991 [monografia]. 2009. . O lado perverso da persuasão. História Viva, São Paulo, p. 66-71, 01 jul.

MARTINS, Jorge S..Redação publicitária: teoria e prática. São Paulo: Atlas, 1997.

MEMÓRIA GLOBO. Debate Collor x Lula. [s.d.]. Disponível em:

$<$ http://memoriaglobo.globo.com/erros/debate-collor-x-lula.htm>. Acesso em: 20 maio 2017.

PEREZ, Clotilde. Publicidade transbordante: teoria e práxis. In: ENCONTRO NACIONAL DE PESQUISADORES EM PUBLICIDADE E PROPAGANDA, 7., 2016, Rio de Janeiro.. Acesso em: 20 maio 2017

PINHO, J.B. Propaganda institucional. São Paulo: Summus, 1990.

PUBLICIDADE enganosa e abusiva. Publicidade e consumo - Coleção Educação para o Consumo Responsável. [S.1.]: INMETRO; IDEC, 2002, p. 29-30. Disponível em: <http://www.inmetro.gov.br/inovacao/publicacoes/cartilhas/ColEducativa/publicidade.p df >. Acesso em: 20 maio 2017.

REBOUL, Olivier. O slogan. São Paulo: Cultrix, 1986.

ROCHA, Maria Eduarda da Mota. A nova retórica do grande capital: a publicidade brasileira entre o neoliberalismo e a democratização. Revista Comunicação, Mídia e Consumo. v. 1, n. 2, p. 50-76, jul./dez. 2004. Disponível em:

$<$ http://revistacmc.espm.br/index.php/revistacmc/article/view/13/13>. Acesso em: 17 abr. 2011.

RUBIM, Antonio Albino. Comunicação e política. São Paulo: Hacker, 2000.

WEBER, Maria Helena; ABREU, Carmen R. Debate político-eleitoral na televisão: jogo de cena e dispositivo estratégico. In: MIGUEL, Luis Felipe; BIROLI, Flávia. (Org.). Mídia, representação e democracia no Brasil - estudos sobre comunicação política. São Paulo: Hucitec, 2010, v. 1. p.162-194.

Submetidoem: 31.05 .2018

Aprovadoem: 23.06.2018 